\title{
PENERAPAN MEREK DAN DIGITAL MARKETING DALAM PRODUKSI PANGAN BERAS DESA BANJARSARI
}

\author{
Niken Paramitasari*1, Betty Magdalena ${ }^{2}$ \\ ${ }^{1,2}$ Institut Informatika dan Bisnis Darmajaya \\ e-mail:*1nikenparamitasari@darmajaya.ac.id, ${ }^{2}$ betty_magdalena1969@gmail.com
}

\begin{abstract}
Abstrak
Tujuan dari Pengabdian ini adalah meningkatkan pengetahuan para petani di desa Banjarsari mengenai merek dan membantu mengembangkan pangsa pasar dalam mengenalkan produk beras dengan menerapkan Digital Marketing dengan memanfaatkan teknologi. Pengabdian ini ditujukan kepada masyarakat (petani) di desa Banjarsari. Solusi yang ditawarkan adalah 1) Memberikan sosialisasi bagi masyarakat di desa Banjarsari mengenai kondisi perilaku konsumen di masa pandemi agar dapat menyikapi kondisi dan memanfaatkan peluang yang ada; 2) sosialisasi mengenai pentingnya merek sebagai identitas suatu produk sehingga dapat digunakan sebagai media pemasaran secara offline maupun online; dan 3) membuat desain merek dan produksi cetak kemasan serta memberikan pelatihan Digital Marketing sehingga akses penjualan semakin meningkat. Hasil dari kegiatan ini adalah 1) sosialisasi dan penyuluhan terkait pengetahuan mengenai kondisi dan perilaku konsumen di masa pandemi serta memanfaatkan peluang yang ada dengan menerapkan Digital Marketing berjalan dengan lancar terlihat dari antusias dan termotivasinya peserta dalam mengikuti kegiatan; 2) Beras yang sudah memiliki merek sendiri, sehingga konsumen dan masyarakat lebih mudah untuk mengenali produk beras dan dedak padi dari desa Banjarsari; dan 3) Selain itu para petani juga sudah memiliki pelanggan di luar kota karena mempromosikan produk beras tersebut ke sosial media sehingga menambah segmentasi pasar mereka serta meningkatkan pendapatan para petani.
\end{abstract}

Kata kunci : Digital Marketing, Merek, Petani, Produksi Pangan Beras

\begin{abstract}
The purpose of this service activity is to increase the knowledge of farmers in Banjarsari village about brands and help develop market share in introducing rice products by implementing Digital Marketing by utilizing technology. This service is aimed at the community (farmers) in the village of Banjarsari. The solutions offered are 1) Providing socialization for the community in Banjarsari village regarding the condition of consumer behavior during the pandemic so that they can respond to conditions and take advantage of existing opportunities; 2) socialization about the importance of brand as the identity of a product so that it can be used as a marketing medium both offline and online; and 3) make brand design and print packaging production as well as provide Digital Marketing training so that sales access is increasing. The results of this activity are 1) socialization and counseling related to knowledge about consumer conditions and behavior during the pandemic and taking advantage of existing opportunities by implementing Digital Marketing that runs smoothly as seen from the enthusiasm and motivation of participants in participating in activities; 2) Rice that already has its own brand, so that it is easier for consumers and the public to recognize rice and rice bran products from Banjarsari village; and 3) In addition, the farmers also have customers outside the city because they promote the rice product on social media, thereby increasing their market segmentation and increasing farmers' income.
\end{abstract}

Keywords : Digital Marketing, Brands, Farmers, Rice Food Production 


\section{PENDAHULUAN}

Perubahan lingkungan strategis seperti pandemi Covid-19 telah menyebabkan perubahan dalam manajemen dan pola pangan masyarakat [1]. Pembatasan pergerakan barang dan orang dalam rangka pengendalian penyebaran virus dan dampak yang ditimbulkannya secara langsung dan tidak langsung telah menyebabkan perubahan perubahan pada sistem produksi, distribusi, manajemen stok, serta pola dan jenis konsumsi pangan di masyarakat. Potensi penurunan produksi, instabilitas harga, serta perubahan perilaku dan preferensi konsumsi pangan di masyarakat akibat pandemi Covid-19 perlu diimbangi dengan manajemen pangan yang mampu menyesuaikan dengan perubahanperubahan tersebut sehingga Ketersediaan pangan yang beragam dan mudahnya aksesibilitas pangan dalam jumlah yang cukup [2].

Sistem distribusi pangan merupakan aspek yang paling terdampak oleh pandemi Covid-19. Meskipun sektor pangan merupakan sektor yang dikecualikan dalam kebijakan Pembatasan Sosial Berskala Besar (PSBB), kenyataannya terjadi kenaikan harga pangan dan biaya produksi pangan. Hampir semua perusahaan tidak beroperasi $100 \%$ pada masa pandemi ini. Sebagai gambaran, perusahaan pertanian dan peternakan yang beroperasi sebesar 76,3\%, sedangkan transportasi dan pergudangan lebih kecil lagi, yaitu 58,8\%. Hal ini mengakibatkan sistem distribusi pangan dan pendapatan masyarakat menurun sehingga daya beli menurun, yang pada gilirannya permintaan terhadap pangan tersebut akan cenderung menurun [3].

Tantangan petani beras menjadi semakin kompleks karena pada saat yang sama produksi beras menghadapi ancaman dampak perubahan lingkungan termasuk perubahan iklim [4] (terutama kekeringan), serta alih fungsi lahan [5] pertanian yang kecenderungannya semakin besar. Sebagai gambaran, berdasarkan data BPS dengan metode penghitungan KSA, luas panen padi nasional pada tahun 2019 mengalami penurunan sebesar $6,15 \%$ menjadi 10,8 juta hektare dibanding tahun 2018. Sementara itu, produksi padi turun $7,75 \%$ menjadi 54,60 juta ton GKG. Kondisi ini menjadi semakin berat mengingat kinerja perdagangan beras antarpulau dan sistem logistik pendukungnya belum sepenuhnya siap menghadapi perubahan akibat pandemi ini. FAO (2020) memberi peringatan kepada semua negara untuk mengantisipasi terjadinya krisis pangan agar kelaparan dan kekurangan gizi tidak bertambah banyak. FAO juga menghimbau semua negara untuk bekerja sama membentuk kembali sistem pangan dengan menyelaraskan produksi dan konsumsi pangan.

Manajemen penyediaan beras merupakan salah satu manajemen pangan yang harus dilakukan secara sungguh-sungguh mengingat beras merupakan komoditas pangan utama bagi sebagian besar penduduk Indonesia. Tingkat partisipasi konsumsi beras hampir 100\%, yang 
berarti setiap orang mengonsumsi beras, termasuk masyarakat yang sebelumnya mempunyai pangan pokok nonberas [6]. Oleh karena itu, strategi jangka pendek, menengah, dan panjang dalam membangun manajemen pangan pascapandemi harus segera dilakukan. Karena peran beras sangat penting dalam meningkatkan ketahanan pangan nasional [7].

Sehingga berdasarkan masalah diatas penelitian ini memfokuskan pada memperdayakan potensi dan sumber daya yang dimiliki desa Banjarsari. Berdasarkan hasil observasi kondisi masyarakat (petani) di desa Banjarsari sebenarnya sangatlah berpotensial dikarnakan banyaknya lahan pertanian dan banyaknya sungai yang membentang yang memudahkan untuk sistem perairan untuk pertanian.

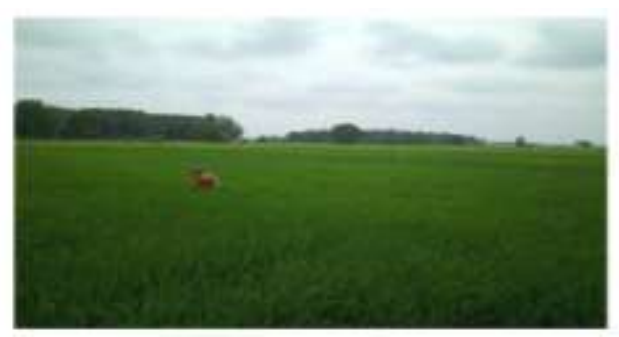

Gambar 1. Kondisi lahan pertanian di desa Banjarsari
Jika dilihat dari gambar 1 kondisi lahan pertanian milik masyarakat (petani) di desa Banjarsari sangat melimpah dan sangat berpotensi untuk menghasilkan beras yang berkualitas namun pada kenyataannya sangat disayangkan karena sedikitnya masyarakat yang mengerti tentang pengaplikasian sistem manajemen yang baik dan benar dan tentang pertanian yang seharusnya dilakukan, perekonomian masyarakat desa Banjarsari adalah menengah kebawah dan perekonomian mereka sangatlah bergantung pada hasil tani. Hasil tani yang digeluti ialah beras. Petani beras di desa Banjarsari selama ini menjual hasil taninya dengan merek kosong atau belum mempunyai merek sendiri bahkan dikemas dalam karung bekas merek produk lain. Padahal beras yang dihasilkan memiliki kualitas yang baik namun karena tidak memiliki merek (brand) tersendiri membuat beras hasil petani di desa Banjarsari ini kurang diminati masyarakat. Berikut ini merupakan contoh produk beras yang belum memiliki merek.
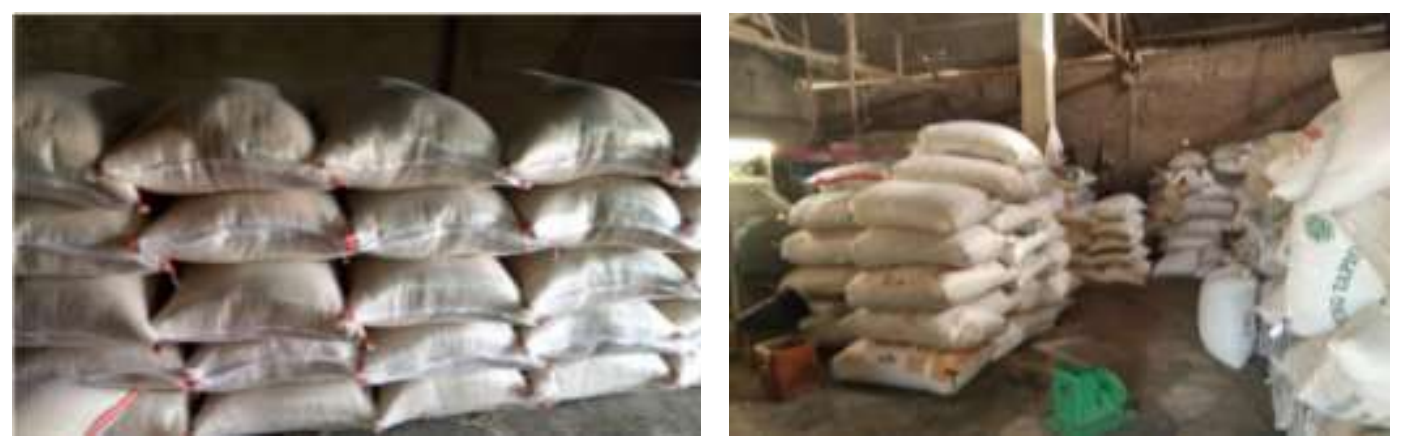

Gambar 2. Beras petani di desa Banjarsari yang belum memiliki merek (Brand) 
Berdasarkan gambar 2 diatas dapat dilihat jumlah beras yang dihasilkan oleh petani di desa Banjarsari sangat banyak namun dikarenakan keterbatasan petani yang tidak memiliki merek (brand) membuat beras yang dijual kurang mendapatkan perhatian dari masyarakat lainnya. Padahal petani menjual beras dengan harga per $1 \mathrm{~kg}$ sebesar Rp. 9,000/kg dan tidak hanya menjual beras para petani juga menjual dedak padi yang dikemas karung ukuran $25 \mathrm{~kg}$ sebesar Rp 20.000 untuk menambah pengasilan mereka. Namun tidak hanya itu masalah yang dihadapi para petani tidak hanya belum memiliki merek (brand) tersendiri dari hasil produksi beras namun cara atau proses penjualannya juga masih menggunakan cara konvensional yaitu dengan cara menawarkan beras dan dedak padi kepada para tetangga sekitar dan menjualnya kepasar hanya sebatas daerah Banjarsari saja. Hal ini juga membuat petani beras di desa Banjarsari memiliki pengahasilan yang masih dibawah rata-rata padahal mereka memiliki sumberdaya yang melimpah namun belum bisa memanfaatkan teknologi untuk membantu memasarkan produk beras yang dihasilkan oleh petani di desa
Banjarsari ke masyarakat lain diluar desa tersebut.

Adapun tujuan atau harapan dari kegiatan pengabdian masyarakat ini yaitu meningkatkan pengetahuan para petani di desa Banjarsari mengenai merek (brand) untuk beras para petani di desa Banjarsari. Selain itu, kegiatan pengabdian masyarakat ini juga bertujuan untuk membantu para petani di desa Banjarsari untuk mengembangkan pangsa pasar mereka dalam mengenalkan produk beras tersebut dengan menerapkan Digital Marketing (pemasaran digital) yang memanfaatkan teknologi agar memiliki jangkauan pasar yang lebih luas tidak hanya dikenal di wilayah desa Banjarsari saja.

\section{METODE}

Penyelesaian masalah bagi petani di desa Banjarsari agar dapat bersaing di masa pandemi Covid-19, yaitu dengan pembuatan merek dan penerapan model bisnis berbasis digital sehingga dapat mempersempit permasalahan pemasaran. Tim dalam pelaksanaannya membagi kegiatan pengabdian menjadi 6 (enam) tahap untuk merealisasikan tujuan tersebut. 


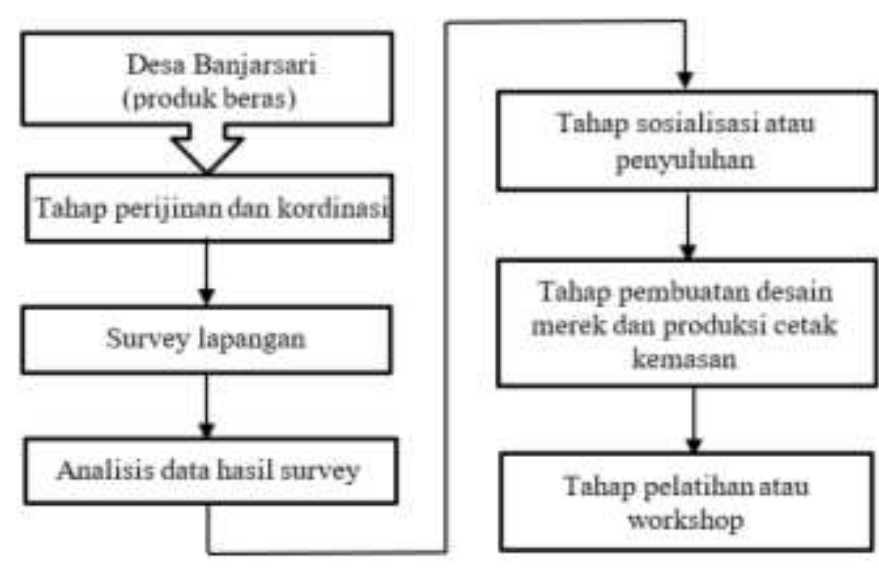

Gambar 3. Tahap Pelaksanaan Pengabdian

Awalnya tahap perijinan dan koordinasi dilakukan dengan aparat desa dan kelompok tani di desa Banjarsari yang fokus pada potensi yang dimiliki desa tersebut yaitu di sektor pertanian beras. Tahap survey dilakukan dengan melakukan kunjungan lapangan ke sawah dan pabrik penggilingan padi serta untuk mengidentifikasi permasalahan para petani melalui wawancara. Dilanjutkan analisis data hasil survey yang dilakukan dengan menyusun rencana kegiatan meliputi penyusunan materi dalam kegiatan sosialisasi, rencana pembuatan desain kemasan dan produksi cetak kemasan, serta penyusunan materi kegiatan pelatihan.

Selanjutnya terdapat 3 tahap kegiatan utama yang dilakukan meliputi kegiatan sosialisasi atau penyuluhan mengenai kondisi perilaku konsumen di masa pandemi Covid-19, memberi pengetahuan dasar mengenai merek dan Digital Marketing. Tahap berikutnya adalah pembuatan desain merek meliputi sketsa, perancangan desain dan produksi cetak kemasan. Tahap terakhir adalah pelatihan atau workhop yang menerapkan konsep Digital Marketing dengan teknik memanfaatkan teknologi dan aplikasi untuk memasarkan hasil tani Banjarsari melalui media sosial.

\section{HASIL DAN PEMBAHASAN}

Kegiatan pengabdian dilakukan saat mulai masa panen hingga proses memanen padi, menjemur dan juga pada saat proses penggilingan. Selama proses itu, dilakukan beberapa 6 tahapan kegiatan dalam Penerapan Merek dan Digital Marketing Pada Produksi Pangan Beras Desa Banjarsari.

Tahap perijinan mulai dilakukan pada tanggal 16 Februari 2021 menemui Kepala RT 02 Desa Banjarsari. Selanjutnya dipertemukan dengan Bapak Amran Rosadi selaku pemilik usaha sekaligus petani beras dan dilakukan koordinasi untuk pelaksanaan kegiatan pengabdian. 
Survey lapangan meliputi kunjungan ke sawah, kunjungan ke penggilingan beras dan meninjau proses pengemasan beras serta dedak. Kegiatan ini bertujuan untuk mengidentifikasi permasalahan pelaku usaha dan hasilnya adalah dalam proses pengemasan belum ada merek, beberapa karung menggunakan karung bekas dengan merek produk lain; belum dijual dan dikemas dalam karung $10 \mathrm{~kg}$ yang bisa di ecer; petani menjual langsung kepengepul dalam karung besar atau dipasarkan ke masyarakat terdekat; dan belum dilakukan pemasaran secara online. Adapun dedak dijual bila ada pemesanan dalam karung ukuran $25 \mathrm{~kg}$.
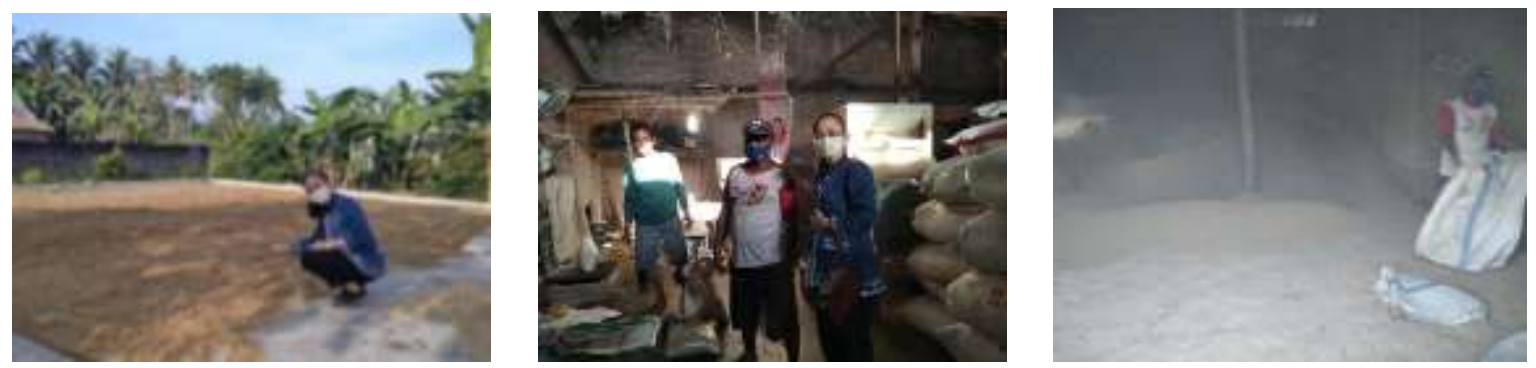

Gambar 4. Penjemuran dan penggilingan padi serta pengemasan dedak

Tahapan hasil analisis dilakukan pendataan hasil survey dan kebutuhan yang diperlukan, yaitu (1) kurang pemahaman akan ilmu pengatahuan baru mengenai dunia usaha dan kondisi perilaku konsumen di masa pandemi Covid-19, maka perlu dilakukan sosialisasi dan penyusunan materi meliputi materi pengetahuan mengenai perilaku konsumen di masa pandemi Covid19. Meski pangan adalah kebutuhan pokok, namun terdapat perilaku baru yang perlu dipahami oleh para pelaku usaha dalam memasarkan produknya. Sosialisasi kedua yaitu mengenai pengetahuan tentang merek, dimana hasil tani yang ada sama sekali belum memiliki merek serta sosialisasi mengenai Digital Marketing yang perlu dipahami sebelum dilakukan proses pelatihan. (2) Tidak adanya merek yang tertera pada kemasan beras hasil tani Banjarsari, maka perlu dibuat desain merek yang menjadi identitas hasil tani Banjarsari, serta produksi cetak kemasan baru $10 \mathrm{~kg}$ yang bermerek untuk padi dan dedak. (3) Kurangnya wilayah pemasaran yang dilakukan oleh petani maka setelah adanya kemasan dan merek baru, perlu dilakukan pemasaran yang lebih luas dengan memanfaatkan teknologi informasi seperti internet dan beberapa aplikasi dengan konsep Digital Marketing. Untuk itu perlu dilakukan pelatihan bagi petani agar setelah kegiatan pengabdian berakhir, kegiatan pemasaran dapat terus berlanjut.

Tahap sosialisasi atau penyuluhan dilakukan di desa Banjarsari RT 02 yang mengundang beberapa petani. Karena beberapa ilmu yang disampaikan 
memerlukan teknologi, maka mengundang juga pihak keluarga yang masih muda dan paham akan penggunaan teknologi. Beberapa materi yang disampaikan yaitu "Kiat sukses usaha di masa pandemi Covid 19”, guna menyikapi perilaku konsumen yang ada saat ini, dan sosialisasi dengan materi "Branding dan Digital Marketing" guna memahami pentingnya merek selain sebagai perlindungan hukum, tentu sebagai identitas suatu produk sehingga memudahkan petani memasarkan baik secara offline maupun online dengan menerapkan Digital Marketing. Dalam penyampaian materi tersebut juga menjelaskan bagaimana membuat content marketing yang menarik untuk mempromosikan usahanya.

Tahap pembuatan desain merek dan produksi cetak kemasan melibatkan mahasiswa sebagai desainer dan melibatkan pelaku usaha dalam penentuan desain. Adapun merek yang dibuat untuk beras dan dedak. Kemudian dilakukan produksi cetak kemasan $10 \mathrm{~kg}$ untuk beras dan cetak stiker untuk kemasan dedak ukuran 500 gr. Beras yang telah dikemas dijual dengan harga 9000/kg, sementara dedak padi yang dikemas dijual dengan harga 5000/kemasan agar lebih menguntungkan bagi penjual agar pendapatan dapat meningkat dari hari biasanya.
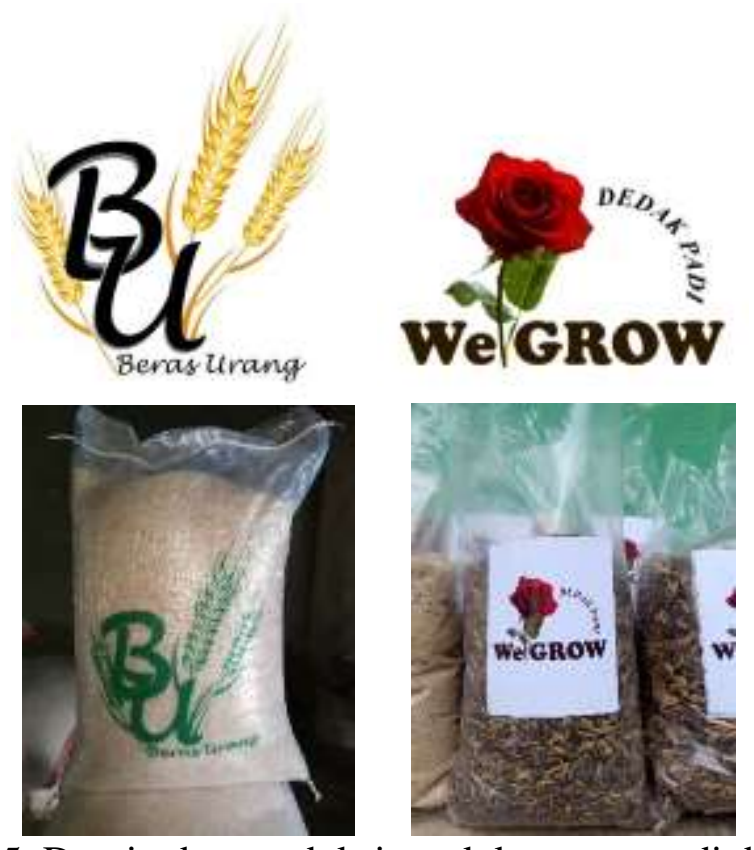

Gambar 5. Desain dan produksi cetak kemasan padi dan dedak

Tahap pelatihan dan workshop dilakukan dengan memanfaatkan teknologi informasi berupa internet dan beberapa aplikasi guna memperluas pasar. Tak dapat dipungkiri bahwa media sosial saat ini digunakan sebagai alternatif bagi setiap pemilik usaha untuk memasarkan produk atau memperkenalkan bisnisnya dengan cepat. Memasarkan produk yang kita miliki melalui jasa media sosial adalah salah satu strategi pemasaran yang efektif, mengingat 
besarnya pengaruh media sosial ini sebagai tempat pengumpulan informasi bagi aspek dan lapisan masyarakat modern di zaman sekarang. Sebelum melakukan proses pembuatan akun Faebook, Instagram dan Whatsapp Bisnis, terlebih dahulu menyiapkan akun gmail, karena akun gmail ini sangat penting dalam proses pembuatan akun tersebut. Untuk akun dimiliki oleh putri dari petani yang mampu mengoperasikan teknologi dan melakukan proses pelayanan.

Selain penggunaan media sosial, juga dilakukan sistem live streaming dengan aplikasi "LIKEE". Banyak pengguna aplikasi tersebut yang melalukan proses baik jual beli maupun konten hiburan sehingga masih layak digunakan sebagai media promosi. Aplikasi juga tidak memungut biaya sama sekali untuk para pedagang yang ingin berniaga di aplikasi tersebut.
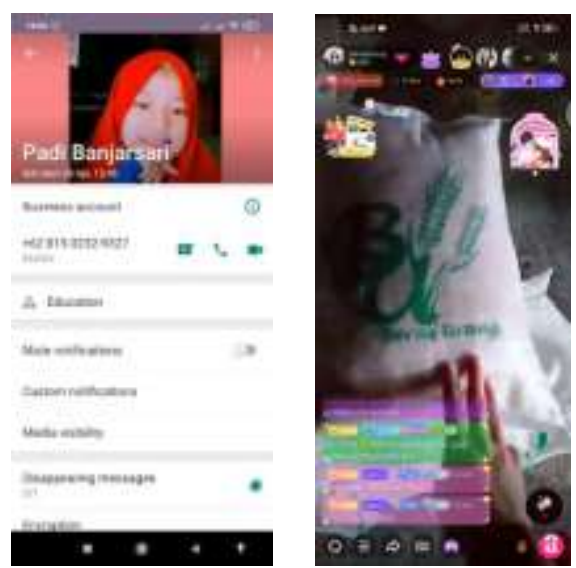

Gambar 6. Akun Whatsapp Business dan Promosi Live Streaming

\section{SIMPULAN}

Dari pembahasan kegiatan pengabdian masyarakat ini dapat disimpulkan bahwa:

1. Dalam kegiatan sosialisasi dan penyuluhan kepada warga Desa Banjarsari terkait pengetahuan mengenai kondisi dan perilaku konsumen di masa pandemi serta memanfaatkan peluang yang ada dengan menerapkan Digital Marketing sudah berjalan dengan lancar terlihat dari antusias dan termotivasinya peserta dalam mengikuti kegiatan.

2. Beras yang dihasilkan oleh petani desa Banjarsari saat ini sudah memiliki merek (brand) sendiri. Sehingga konsumen dan masyarakat sekarang lebih mudah untuk mengenali produk beras dan dedak padi dari desa Banjarsari.

3. Selain itu para petani juga sudah memiliki pelanggan di luar kota dan daerah karena mempromosikan produk beras tersebut ke sosial media facebook, instagram dan whatsapp sehingga menambah segmentasi pasar mereka serta meningkatkan pendapatan para petani.

\section{SARAN}

Saran dalam penelitian ini adalah sebagai berikut : 
1. Supaya produk bisa lebih dikenal masyarakat, produk harus memiliki logo/merek.

2. Menggunakan lebih banyak media sosial untuk promosi dan tidak berpatokan pada satu media sosial saja.

3. Diadakannya kegiatan rutin yang berkenaan dengan kebudayaan atau desa memberikan wadah untuk mengapresiasi hasil karya seni warga desa setempat

\section{UCAPAN TERIMA KASIH}

Penulis mengucapkan terima kasih atas support finansial kepada Ibu Dr. Sri Lestari, M.Cs dari Lembaga Penelitian dan Pengabdian Masyarakat (LPPM) IIB Darmajaya. Terima kasih juga penulis ucapkan kepada RT 2 Desa Banjarsari, Kalianda serta Bapak Amran Rosadi selaku pemilik UKM Beras dan juga Aulia Sebagai pengurus dan juga pengelola UKM yang telah memberikan kesempatan dan meluangkan waktu dalam memberikan kesempatan kepada saya untuk melakukan penelitian terkait penerapan merek dan digital marketing dalam produksi pangan beras di Desa Banjarsari.

\section{DAFTAR PUSTAKA}

[1] M. C. B. Umanailo, "Ketahanan Pangan Lokal dan Diversifikasi Konsumsi
Masyarakat (Studi pada Masyarakat Desa Waimangit Kabupaten Buru)," SOCA J. Sos. Ekon. Pertan., vol. 12, no. 1, pp. 6374 , 2018 , doi: 10.24843/soca.2018.v12.i01.p05.

[2] I. Khomah and R. U. Fajarningsih, "Peningkatan Kualitas Pangan Rumah Tangga," J. Dianmas, vol. 5, no. 2, pp. 81-90, 2016.

[3] A. Nasution, B. Krisnamurthi, and D. Rachmina, "Analisis Permintaan Pangan Rumah Tangga Penerima Manfaat Bantuan Pangan Non Tunai (BPNT) Di Kota Bogor," Forum Agribisnis, vol. 10, no. 1, pp. 1-10, 2020, doi: 10.29244/fagb.10.1.1-10.

[4] A. Raksanagara, N. Arisanti, and F. Rinawan, "Dampak Perubahan Iklim Terhadap Kejadian Demam Berdarah Di Jawa-Barat," J. Sist. Kesehat., vol. 1, no. 1, pp. 43-47, 2016, doi: 10.24198/jsk.v1i1.10339.

[5] O. Putryana and A. Marlina, "Implementasi Kebijakan RTRW pada Zonasi Fungsi Ruang di Lingkungan Sekitar Pasar Silir Semanggi Pasca Alih Fungsi Lahan Implementation of RTRW on Zoning of Space Function in Environment around Silir Semanggi Market Post-Transfer of Land Function," Reqion J. Pembang. Wil. dan Perenc. Partisipatif, vol. 14, no. 1, pp. 80-95, 2019 . 
[6] M. Ariani, "Dinamika Konsumsi Beras, Jagung, dan Kedelai Mendukung Swasembada Pangan," Badan Penelit. dan Pengemb. Pertan., 2015, [Online]. Available: www.litbang.pertanian.go.id.

[7] Sumarno and J. R. Hidayat, "Perluasan Areal Padi Gogo sebagai Pilihan untuk Mendukung Ketahanan Pangan Nasional," Iptek Tanam. Pangan, vol. 2, no. 1 , pp. 26-40, 2015. 